\title{
Determination of the Average Daily Intake of Polychlorinated Biphenyl (PCB) in Breastfed Babies in Vali-Asr Hospital, Tehran University of Medical Sciences
}

\author{
Mosein Zalili ${ }^{1}$, atemeh Gayeri ${ }^{2}$, Samak Fhariat ${ }^{2}$, Cafe Rhongarh ${ }^{{ }^{*}}$ and Meinab Davyani ${ }^{1}$ \\ ${ }^{1}$ Breastfeeding Research Center, Tehran University of Medical Sciences, Tehran, Iran \\ ${ }^{2}$ Maternal-Fetal \& Neonatal Research Center, Family Health Institute, Tehran University of Medical Sciences, Tehran, Iran \\ *Corresponding author: Rhongarh C, Breastfeeding Research Center, T ehran University of Medical Sciences, T ehran, Iran, T el: 0982161 192407; Fax: \\ 0982166591315; E-mail: dr.sabagh@yahoo.com
}

Received date: January 23, 2018; Accepted date: February 20, 2018; Published date: February 28, 2018

Copyright: $\odot 2018$ Zalili $\mathrm{H}$, et al. This is an open-access article distributed under the terms of the Creative Commons Attribution License, which permits unrestricted use, distribution, and reproduction in any medium, provided the original author and source are credited.

\begin{abstract}
Objective: Breast milk is rich in fat. Toxins, pollutants, drugs, and allergens, especially lipophilic toxins may accumulate in the breast milk; therefore, it can serve as potential source for transferring these toxins to the baby. Dioxins, including polychlorinated biphenyl (PCBs) are among these pollutants. The aim of this study was to determine the average daily intake of PCBs in breastfed babies.

Materials and methods: Fifty breast milk samples were collected from breastfeeding mothers whose babies were born in Vali-Asr Hospital, Tehran, Iran in 2014. Each sample was $20 \mathrm{cc}$ and collected within the first 7 days after delivery. PCBs were measured using the GCMass method. We calculated the ADI based on $\mathrm{ng} / \mathrm{kg} / \mathrm{day}$ and compared it with tolerable daily intake (TDI). TDI was considered $20 \mathrm{ng} / \mathrm{kg} /$ day according to WHO.

Results: The mean PCB concentration was $250.65 \mathrm{ng} / \mathrm{gl} . \mathrm{w}$ in the collected samples. Among the 6 isomers measured, the concentration of PCB180<PCB153<PCB101<PCB138<PCB52<PCB28. The average daily intake of the babies was $0.498 \mu \mathrm{g} / \mathrm{kg} / \mathrm{day}$.

Conclusion: Studies in different countries have shown different PCB concentrations in the breast milk. What is interesting is a decrease in the concentration of pollutants in recent years. A decrease has also been noted in Iran, as well. Since breast milk is still the first and the best source of nutrition for new-born infants, more efforts are needed to reduce the amount of pollutants in the breast milk. Since PCB enters the body via inhalation and dermal contact and stores in the fat tissue, and foods like fish, eggs, dairy products, and meat of wild animals are more likely to transfer this compound to the human body, it is important to control the quality of food products especially in pregnant women.
\end{abstract}

Keywords: PCBs; Human milk; ADI; TDI

\section{Introduction}

Industrial lifestyle and increased use of chemicals in everyday living has exposed humans to a variety of toxins and pollutants. The presence of these compounds in the breast milk and their adverse effects are one of the main concerns of perinatalogists [1]. In this regard, Laug et al. reported the presence of DDT in the breast milk for the first time in 1951 and in 1966, Jensen reported the presence of PCB in the breast milk [2,3]. Evaluation of pollutants in the breast milk is important because it may serve as an index of pollution in the general population. In 1999, Patandin found that toxins were traceable until 25 years of age in $12 \%$ of the boys and $14 \%$ of the girls who were breastfed for 6 months [4]. In this study, breast milk pollution with chlorinated hydrocarbons, especially PCB, was investigated. This compound has 209 isomers that are different in terms of total number of atoms and their position on the benzene ring. Their stability and toxicity is also different [5]. These pollutants are not entirely metabolized and can be found in trace amounts everywhere. They also have a cumulative effect and can accumulate in live tissues and human food chain even after exposure cessation due their lipophilic nature and cumulative effect.
Via intake of some foods like the fish, meat, and cheese, these compounds store in the human fat tissue and transfer to the foetus during pregnancy or to the baby through lactation [6]. One study followed up children up to the age of 7 years and found that maternal exposure to PCB affected the growth and development of the babies. These babies had a smaller head circumference and lower weight, received lower scores on psychological and behavioural tests, and had lower IQ scores [7,8]. Moreover, organochlorines affect endocrine glands, e.g. the thyroid, and the immune system, and induce hormonal changes [9-12]. Exposure to PCB increases the occurrence of some diseases like Hodgkin's lymphoma, diabetes, and liver diseases [13]. This study was conducted to determine the concentration of these toxins in the breast milk and the mean dietary intake of babies through breastfeeding.

\section{Methods and Materials}

This cross-sectional descriptive analytical study was conducted on 50 breast milk samples collected from mothers within one week of delivery in Vali-Asr Hospital, Tehran, Iran. Mothers aged 25-45 years $($ mean=29) who did not smoke or use illicit drugs and did not have direct occupational exposure to pollutants (like working in fabric, pain, 
Citation: Dalili H, Nayeri F, Shariat M, Ghorbansabagh V, Kavyani Z (2018) Determination of the Average Daily Intake of Polychlorinated Biphenyl (PCB) in Breastfed Babies in Vali-Asr Hospital, Tehran University of Medical Sciences. Clinics Mother Child Health 15: 287. doi:10.4172/2090-7214.1000287

Page 2 of 4

or wood factories) were included in the study. None of the mothers suffered from chronic diseases, like diabetes and hypertension, or systemic diseases. Demographic characteristics are listed in table 1. 20 $\mathrm{ml}$ of milk was collected by the mother or the nurse in 4 sterile bottles, sent to the lab, and stored at $-20^{\circ} \mathrm{C}$. In the next step, all frozen samples were sent to the laboratory of Research Center of Environment for further analysis using the GCMass 19/20/21 method to measure the concentration of PCB28, PCB52, PCB101, PCB138, PCB153 and PCB180 isomers [8].

\begin{tabular}{|l|l|l|l|}
\hline \multicolumn{2}{|l|}{ Variable } & Frequency & Frequency \% \\
\hline \multirow{2}{*}{ Employed } & Yes & 4 & 84.3 \\
\cline { 2 - 4 } & No & 43 & 7.8 \\
\hline \multirow{2}{*}{ Educational level } & Under Diploma & 15 & 33.3 \\
\cline { 2 - 4 } & More than Diploma & 30 & 67.7 \\
\hline \multirow{2}{*}{ Parity } & 1 & 18 & 35.3 \\
\cline { 2 - 5 } & $>1$ & 33 & 65.7 \\
\hline
\end{tabular}

Table 1: Demographic criteria

We used the Solid Phase Micro Extraction (SPME) method to evaluate the concentration of pollutants. In this method, very tiny fibres is used, the surface of which is coated with polymers made of dimethyl siloxane. It is used to extract analysis from different kinds of matrices. In the present study, we applied the head space SPME (HSSPME) technique using the GC-MS/MS device.

We calculated the ADI using the following formula: ADI (ng/ $\mathrm{kg})=$ Average daily intake $\left(\mathrm{PCB}^{*} \mathrm{BW}^{*}\right.$ breast milk (L)/BW [14].

In our study, the mean daily intake of breast milk was considered as much as $150 \mathrm{cc}$ in first week of life [15]. Then, ADI and tolerable daily intake (TDI) were compared. TDI was considered $20 \mathrm{ng} / \mathrm{kg} / \mathrm{day}$ according to the WHO [16]. Moreover, the concentration of this pollutant was compared between primiparous and nulliparous women and the age distribution of mothers were also evaluated. The protocol and objective of the study was explained to mothers and informed consent was taken from all of them before joining the study. The collected information was confidential and only the results were published. This study was done under ethical permission from Tehran University of Medical Science number 27084.

\section{Results}

The concentration of PCB28, PCB52, PCB101, PCB138, PCB153, and PCB180 was measured in the breast milk one week after delivery (Table 1). The mean PCB concentration was $250.65 \mathrm{ng} / \mathrm{gl} . \mathrm{w}$ in the collected samples. The highest concentration of isomers to the lowest were $\quad$ PCB28 $>$ PCB52 $>$ PCB138 $>$ PCB101 $>$ PCB153 $>$ PCB180 respectively. The mean fat concentration in the breast milk was 13.2679 $\pm 7.97 \mathrm{~g} / \mathrm{l}$. The average daily intake (ADI) of the neonates was 498 $\mathrm{ng} / \mathrm{kg} /$ day, which was higher than the TDI suggested by the WHO. There was no significant difference in the PCB concentration between primiparous and nulliparous women. PCB concentration had no correlation with maternal age.

\section{Discussions and Conclusion}

Numerous studies have shown that PCBs have many toxic effects on different body organs. Environmental accumulation of organochlorins has effect on endocrine, immune system and increases the risk of prostate cancer, Breast cancer, endometriosis cryptorchidism and hypospadiasis as well as long term its impact on evolution of the intelligence and neurobehavioral system and may cause delayed CNC growth.

Many pollutants enter the body via food substances. In one study investigating the concentration of $\mathrm{PCB}$ in the butter in Iran, the highest concentration was found in Mazandaran Province, north of Iran, and in large cities like Tehran, Isfahan, and Arak. These cities are among the most industrialized and polluted cities of Iran. The lowest concentration was seen in West Azerbaijan and Qazvin, which are both dairy products constitute a major of everyday diet [17]. In this study, the mean PCB was $250.65 \pm 280.3 \mathrm{ng} / \mathrm{glw}$ and the highest concentration of isomers to the lowest were PCB28 $>$ PCB52 $>$ PCB138 $>$ PCB101 $>$ PCB153 $>$ PCB180 respectively. The $\mathrm{ADI}$ of the neonates was $498.79 \mathrm{ng} / \mathrm{kg} / \mathrm{day}$, which was higher than the WHO tolerated daily intake (TDI). Table 2 shows ADI in the number of countries.

\begin{tabular}{|l|l|}
\hline Variable & Mean \pm SD $(\mathbf{n g} / \mathbf{g l w})$ \\
\hline PCB28 & $446.1 \pm 181.64$ \\
\hline PCB52 & $370 \pm 206.5$ \\
\hline PCB138 & $308.9 \pm 1111.7$ \\
\hline PCB101 & $149.9 \pm 78.08$ \\
\hline PCB153 & $145.4 \pm 78.2$ \\
\hline PCB180 & $83.6 \pm 28.6$ \\
\hline ГPCB & $250.65 \pm 280.3$ \\
\hline
\end{tabular}

Table 2: The mean score of PCBs level in human milk samples

In a study in Italy, in 2011, 50 number of the breast milk of the mothers who ate a lot of fish was a good source of PCBs, the mean PCB concentration was $532.87 \mathrm{ng} / \mathrm{glw}$ in the breast milk and had no correlation with maternal age, primiparity, and multiparity [18].

A study was conducted on 22 milk samples in India in 2004-2005. Fish consumption in different parts of the country led to an increase in the concentration of PCB in the breast milk. The PCB concentration was $330 \pm 220$ and $220 \pm 140 \mathrm{ng} / \mathrm{glw}$ in the breast milk of primiparous and multiparous women respectively with no significant difference [19].

A study in India in 2009 showed a significant decrease in the breast milk PCB concentration [20].

A study was conducted in Iran to measure the PCB concentration in 50 breast milk samples and to evaluate its association with maternal diet. The concentration of PCB 28 and 180 was significantly higher in mothers with higher poultry consumption, while the concentration of PCB 153 was significantly lower in mothers with higher fish consumption [21].

According to a research on human breast milk samples in Tabriz, Iran in 2007, the concentration of PCBs in the breast milk was $690 \mathrm{ng} /$ 
Citation: Dalili H, Nayeri F, Shariat M, Ghorbansabagh V, Kavyani Z (2018) Determination of the Average Daily Intake of Polychlorinated Biphenyl (PCB) in Breastfed Babies in Vali-Asr Hospital, Tehran University of Medical Sciences. Clinics Mother Child Health 15: 287. doi: 10.4172/2090-7214.1000287

Page 3 of 4

gl.w, while we detected a much lower concentration $(250.65 \pm 290.3$ ng/gl.w). In the study conducted in Tabriz, the PCB concentration was significantly higher in primiparous women and ADI was $1.4 \mu \mathrm{g} / \mathrm{kg} /$ day but we detected no such difference [22] and ADI was $498 \mathrm{ng} / \mathrm{kg} /$ day in our study, which shows a 7-fold decrease (Figure 1).

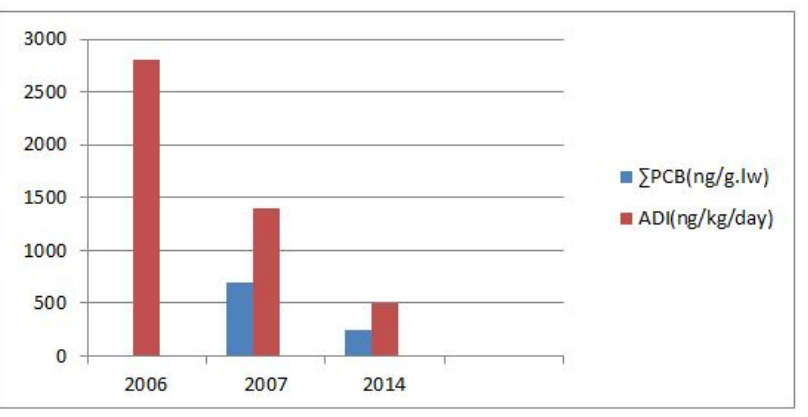

Figure 1: ADI (available daily intake) and $\Sigma \mathrm{PCB}$ in Iran.

In Tabriz study, PCB 180 had the highest concentration among isomers while it had the lowest and PCB 28 had the highest concentration in our study.

In another study conducted in the southern coasts of the Caspian Sea, the average concentration of PCB was $1560 \mathrm{ng} / \mathrm{gl} . \mathrm{w}$ in human breast milk samples, which was markedly higher than our finding [23]. Similar to our results, PCB 28 had the highest concentration in this study and PCB concentration had no correlation with maternal age and number of children. The ADI was $2.8 \mu \mathrm{g} / \mathrm{kg} /$ day in this study, which was markedly higher than the ADI in our study [23].

According to a study in southern parts of India between 2000 and 2003, the PBC concentration was 30-34 ng/gl.w with no significant different between primiparous and multiparous women [24].

During 2004-2006, 64 breast milk samples were evaluated in 3 industrialized cities of India. The results showed that the PCB concentration ranged between 0.063 and $170 \mathrm{ng} / \mathrm{gl} . \mathrm{w}$ and the ADI was less than standard (Table 3) [25].

\begin{tabular}{|l|l|l|}
\hline Country & ADI $(\boldsymbol{\mu g} / \mathbf{k g} /$ day) & $\sum$ PCB $(\mathbf{n g} / \mathbf{g l} . \mathbf{w})$ \\
\hline India (2000-2003) & Unknown & $30-34$ \\
\hline India (2004-2006) & Unknown & $0.063-170$ \\
\hline Turkey (2012) & 0.052 & 8.073 \\
\hline Tunisia (2008) & 0.83 & 196 \\
\hline Russia (2007) & 0.77 & $69-680$ \\
\hline Korea (2013) & Unknown & 38.08 \\
\hline Canada (2014) & Unknown & $9.8-510$ \\
\hline Iran (2006) & 2.8 & 1560 \\
\hline Iran (2007) & 1.4 & 690 \\
\hline Iran (2014) & 0.498 & 250.65 \\
\hline
\end{tabular}

Table 3: Breast milk $\Sigma$ PCB in some country.
The breast milk PCB concentration ranged from 69 to $680 \mathrm{ng} / \mathrm{gl} . \mathrm{w}$ in a study in Russia in 2003-2004. The concentration of PCB was higher in older and primiparous mothers although the difference was not statistically significant. The ADI was $0.77 \mu \mathrm{g} / \mathrm{kg} / \mathrm{day}$, which was higher than the standard [26].

The results of a study in Iran showed maternal age had no significant correlation with $\mathrm{PCB}$ concentration while a significant positive relationship was observed between PCB 101 and 28 concentration and BMI [27].

In a study conducted in Mersin, Turkey in 2009, the mean PCB concentration in 47 breast milk samples was $8.073 \mathrm{ng} / \mathrm{gl} . \mathrm{w}$ and the ADI of the neonates was $0.052 \mu \mathrm{g} / \mathrm{kg} /$ day. The TDI was considered $1 \mu \mathrm{g} / \mathrm{kg}$ in this study. PCB 153 and PCB 52 had the highest and lowest concentration, respectively [14].

A total of 237 breast milk samples were evaluated in Tunisia in 2002-2005. The mean PCB concentration was 196 ng/gl.w. PCB 153 and PCB 28 had the highest and lowest concentration, and ADI and TDI was 0.83 and $1 \mu \mathrm{g} / \mathrm{kg} /$ day, respectively [28].

The mean PCB concentration was 38.3 ng/gl.w in 50 breast milk samples in a study in Korea in 2013, indicating a decrease in comparison with previous years. PCB concentration was correlated with the duration of living in the region but had no relationship with maternal diet. In this study, ADI was higher than standard in $18 \%$ of the babies [29].

In 298 samples collected between 2008 and 2010 in Canada, the mean PCB concentration was 9.8-510 ng/gl.w. The toxic dose was considered 2.7-27 ng/gl.w in this study. PCB 153 and PCB 118 had the highest and lowest concentration, respectively [30].

Although the concentration of PCB was high in breast milk samples in our study and ADI was higher standard, breast milk is still the main source of nutrition in babies considering the decrease in this compound in the breast milk. Since PCB enters the body via inhalation and dermal contact and stores in the fat tissue, and foods like fish, eggs, dairy products, and meat of wild animals are more likely to transfer this compound to the human body, it is important to control the quality of food products and pregnant women's diet to promote neonatal health.

\section{Acknowledgement}

This study was supported by grant of Tehran University of Medical Sciences (NO: 27084). We are thankful to the all participants and their parents who have shown enthusiasm towards this project. We are grateful to all nurses and other medical staffs who helped us in this project.

\section{Conflict of Interest}

The authors declare no conflict of interest.

\section{References}

1. Sikorski R, Paszkowski T, Radomanski T, Radomanski A, Semeniukt S (1990) Human colostrum as a source of organohalogen xenobiotics for a breast-fed neonate. Reprod Toxicol 4: 17-20.

2. Laug EP, Kunze FM, Prickett CS (1951) Occurrence of DDT in human fat and milk. AMA Arch Ind Hyg Occup Med 3: 245-246.

3. Jensen S (1966) Report of a new chemical hazard. New Scientist 32: 445. 
Citation: Dalili H, Nayeri F, Shariat M, Ghorbansabagh V, Kavyani Z (2018) Determination of the Average Daily Intake of Polychlorinated Biphenyl (PCB) in Breastfed Babies in Vali-Asr Hospital, Tehran University of Medical Sciences. Clinics Mother Child Health 15: 287. doi:10.4172/2090-7214.1000287

Page 4 of 4

4. Patandin S, Dagnelie PC, Mulder PGH, Op de Coul E, van der Veen JE, et al. (1999) Dietary exposure to polychlorinated biphenyls and dioxins from infancy until adulthood: A comparison between breast-feeding, toddler, and long-term exposure. Environ Health Perspect 107: 45.

5. Safe S (1990) Polychlorinated biphenyls (PCBs), dibenzo-p-dioxins (PCDDs), dibenzofurans (PCDFs), and related compounds environmental and mechanistic considerations which support the development of toxic equivalency factors (TEFs). Crit Rev Toxicol 21: 51-88.

6. Korrick SA, Altshul L (1998) High breast milk levels of polychlorinated biphenyls (PCBs) among four women living adjacent to a PCBcontaminated waste site. Environmen Health Perspect 106: 513-518.

7. Jacobson JL, Jacobson SW (1996) Intellectual impairment in children exposed to polychlorinated biphenyls in utero. N Engl J Med 335: 783-789.

8. Stewart P, Reihman J, Lonky E, Darvill T, Pagano J (2000) Prenatal PCB exposure and neonatal behavioral assessment scale (NBAS) performance. Neurotoxicol Teratol 22: 21-29.

9. Mendola P, Buck GM, Sever LE, Zielezny M, Vena JE (1997) Consumption of PCB-contaminated freshwater fish and shortened menstrual cycle length. Am J Epidemiol 146: 955-960.

10. Arcaro KF, O'Keefe PW, Yang Y, Clayton W, Gierthy JF (1999) Antiestrogenicity of environmental polycyclic aromatic hydrocarbons in human breast cancer cells. Toxicol 133: 115-127.

11. Carpenter DO (1998) Polychlorinated biphenyls and human health. Int J Occup Med Environ Health 11: 291-303.

12. Schell LM (2002) Polychlorinated biphenyls and thyroid function in adolescents of the Mohawk Nation at Akwesasne. Gilli G, Schell LM, Benso L (eds) Human Growth from Conception to Maturity. SmithGordon, London, pp 289-296.

13. Johnson BL (1999) Public health implications of exposure to polychlorinated biphenyls (PCBs). Washington, DC: Agency for Toxic Substances and Disease Registry (USDHHS) and US Environmental Protection Agency.

14. Cok I, Mazmanci B, Mazmanci MA, Turgut C, Henkelmann B, et al. (2012) Analysis of human milk to assess exposure to PAHs, PCBs and organochlorine pesticides in the vicinity Mediterranean city Mersin, Turkey. Environ Int 40: 63-69.

15. Riordan J, Gill-Hopple K, Angeron J (2005) Indicators of effective breastfeeding and estimates of breast milk intake. J Hum Lact 21: 406-412.

16. http://www.greenfacts.org/en/pcbs/figtableboxes/table-a.htm.

17. Jafari A, Moeckel C, Jones KC (2008) Spatial biomonitoring of persistent organic pollutants in Iran: a study using locally produced butter. J Environ Monit 10: 861-866.

18. Guerranti C, Palmieri M, Mariottini M, Focardi SE (2011) Persistent Organic Pollutants in Human Milk from Central Italy: Levels and Time Trends. ISRN Toxicol 107514.
19. Someya M, Ohtake M, Kunisue T, Subramanian A, Takahashi, et al. (2010) Persistent organic pollutants in breast milk of mothers residing around an open dumping site in Kolkata, India: specific dioxin-like PCB levels and fish as a potential source. Environ Int 36: 27-35.

20. Devanathan G, Subramanian A, Sudaryanto A, Takahashi S, Isobe T, et al. (2012) Brominated flame retardants and polychlorinated biphenyls in human breast milk from several locations in India: potential contaminant sources in a municipal dumping site. Environt Int 39: 87-95.

21. Dalili H, NAYYERI F, Shariat M, Rastkari N, Sabagh VG (2016) Determining of PCB in the milk of nursing mothers its relationship with the mother's diet. Int J Curr Res 8: 33553-33557.

22. Behrooz DR, Sari AE, Bahramifar N, Naghdi F, Shahriyari AR (2009) Organochlorine pesticide and polychlorinated biphenyl residues in human milk from Tabriz, Iran. Environ Toxicol Chem 91: 1455-1468.

23. Behrooz RD, Sari AE, Bahramifar N, Ghasempouri SM (2009) Organochlorine pesticide and polychlorinated biphenyl residues in human milk from the Southern Coast of Caspian Sea, Iran. Chemosphere 74: 931-937.

24. Subramanian A, Ohtake M, Kunisue T, Tanabe S (2007) High levels of organochlorines in mothers' milk from Chennai (Madras) city, India. Chemosphere 68: 928-939.

25. Devanathan G, Subramanian A, Someya M, Sudaryanto A, Isobe T, et al. (2009) Persistent organochlorines in human breast milk from major metropolitan cities in India. Environ Pollut 157: 148-154.

26. Tsydenova OV, Sudaryanto A, Kajiwara N, Kunisue T, Batoev VB (2007) Organohalogen compounds in human breast milk from Republic of Buryatia, Russia. Environ Pollut 146: 225-232.

27. Nayeri F, Dalili H, Shariat M, Esmaeilnia T, Amini E, et al. (2016) The measurement of polychlorinated biphenyl level in breast milk after delivery, and its association with breast milk fat and mother's BMI. Tehran Univ Med J 74: 578-583.

28. Ennaceur S, Gandoura N, Driss MR (2008) Distribution of polychlorinated biphenyls and organochlorine pesticides in human breast milk from various locations in Tunisia: levels of contamination, influencing factors, and infant risk assessment. Environ Res 108: 86-93.

29. Kim D, Ryu HY, Lee JH, Lee JH, Lee YJ, et al. (2013) Organochlorine pesticides and polychlorinated biphenyls in Korean human milk: contamination levels and infant risk assessment. J Environ Sci Health B 48: 243-250.

30. Rawn DFK, Sadler AR, Casey VA, Breton F, Sun W-F, et al. (2014) Persistent organic pollutant concentrationsin human milk from Canada, comparison of current with previous results. Organohal Comp 76: 392-395. 